\title{
LEMBAGA JUDICIAL REVIEW UNDANG-UNDANG TERHADAP UNDANG-UNDANG DASAR : PERBANDINGAN ANTARA KEWENANGAN MAHKAMAH KONSTITUSI KOREA SELATAN DENGAN MAHKAMAH KONSTITUSI REPUBLIK INDONESIA ${ }^{1}$
}

\author{
Oleh: \\ Joseph Atja Sulandra², Anak Agung Ngurah Roy Sumardika ${ }^{3}$
}

\begin{abstract}
This study aimed to compare the profile and authority of the Constitutional Court of South Korea with the Constitutional Court of the Republic of Indonesia, which is granted by its Constitution and related laws. The aim is to see how far the role of the Constitutional Court of the Republic of Indonesia as an institution of judicial review, so that it can also note the advantages and disadvantages in its function as the guardian of the constitution.
\end{abstract}

Keywords: Constitutional Court, the Constitutional Court of the Republic of Indonesia.

\begin{abstract}
Abstrak
Penelitian ini bertujuan untuk membandingkan profil dan kewenangan Mahkamah Konstitusi Korea Selatan dengan Mahkamah Konstitusi Republik Indonesia, yang diberikan oleh Undang-Undang Dasar serta Undang-Undang terkait. Tujuannya adalah untuk melihat seberapa jauh peran Mahkamah Konstitusi Republik Indonesia sebagai Lembaga Judicial Review Undang-undang terhadap Undang-Undang Dasar, sehingga dapat dilihat kelebihan dan kekurangannya masing-masing dalam fungsinya sebagai lembaga pengawal konstitusi.
\end{abstract}

Kata kunci: Mahkamah Konstitusi, Mahkamah Konstitusi Republik Indonesia.

Artikel ini merupakan karya ilmiah mahasiswa pada Program Studi Magister (S2) Ilmu Hukum Program Pascasarjana Universitas Udayana, serta mengucapkan terimakasih kepada Prof. Dr. I Made Pasek Diantha, SH.,MS dan Dr. I Gede Yusa, SH.,MH selaku Pembimbing Tesis

2 Penulis pertama adalah Mahasiswa Program Studi Magister (S2) Ilmu Hukum, Denpasar; Bali. email: sul4ndr4@gmail.com

3 Penulis kedua adalah mahasiswa magister ilmu hukum Universitas Udayana, Denpasar, Bali, email: agung_dps18@yahoo.com 


\section{PENDAHULUAN}

\subsection{Latar Belakang}

Dalam praktek dikenal adanya tiga macam norma hukum yang dapat di review (ditinjau, diperiksa, atau diuji $)^{4}$, yang lazim disebut norm control mechanism $^{5}$. Ketiganya sama-sama berbentuk norma hukum sebagai hasil dari proses pengambilan keputusan hukum, yaitu terdiri dari :

1. Keputusan normatifyang bersifat pengaturan (regeling),

2. Keputusan normatif yang bersifat penetapan administratif (beschikking), dan

3. Keputusan normatifyang bersifat penghakiman (judgement), yang biasa disebut vonis.

Ketiga norma hukum itu dapat diuji kebenarannya melalui mekanisme peradilan/yustisial ataupun melalui mekanisme non-yustisial. Jika hak untuk menguji (toetsingrecht) itu diberikan kepada parlemen sebagai legislator, maka proses pengujiannya disebut sebagai legislative review. Jika hak untuk menguji itu diberikan kepada pemerintah, maka proses pengujiannya disebut sebagai executive review. Jika pengujian tersebut dilakukan oleh lembaga peradilan, maka proses

\footnotetext{
4 Dalam John. M. Echols dan Hassan Shadili, 1993, Kamus Inggris-Indonesia, (An EnglishIndonesian Dictionary), PT Gramedia Pustaka Utama, Jakarta, hlm. 484, kata "review" diterjemahkan sebagai "tinjauan", "pemeriksaan".

5 Jimly Asshiddiqie, 2006, Hukum Acara Pengujian Undang-Undang, Konstitusi Press, Jakarta, hlm. 1.
}

Vol. 5, No. 2 : 368 - 379

http://ojs.unud.ac.id/index.php/jmhu pengujiannya disebut sebagai judicial review, atau pengujian oleh lembaga yudisial atau pengadilan ${ }^{6}$.

Ketiga macam norma hukum tersebut diatas ada yang merupakan individual and concrete norms, dan ada pula yang merupakan general and abstract norms. Vonis dan beschikking selalu bersifat individual and concrete, sedangkan regeling selalu bersifat general and abstract ${ }^{7}$. Di Amerika Serikat, upaya hukum untuk menggugat atau menguji ketiga macam norma hukum tersebut melalui pengadilan disebut dengan judicial review. Pengujian yang dilakukan oleh hakim tingkat banding terhadap putusan hakim tingkat pertama dalam sistem peradilan Amerika Serikat disebut judicial review, demikian juga dalam pengujian kasasi oleh Mahkamah Agung (Supreme Court) terhadap putusan pengadilan di bawahnya disebut juga judicial review. Dalam mengadili gugatan-gugatan perkara tata usaha negara terhadap keputusan-keputusan administrasi negara, para hakim di Amerika Serikat juga menggunakan istilah judicial review.

Dalam Black's Law Dictionary, makna dari judicial review adalah: “1). A court's power to review the actions of other branches or levels of government; esp., the court's power

Ibid., hlm. 1-2.

Ibid., hlm. 4. Periksa lebih jauh Hans Kelsen, 2006, General Theory of Law and State, with new introduction by A. Javier Trevino, Transaction Publisher, New Brunswick (USA) and London (UK), hlm. 37-38. 
to invalidate legislative and executive action as being unconstitutional. 2). The constitutional doctrine providing for this power. 3). A court's review of a lower court's or an administrative body's factual or legal findings"8. Makna pertama dari rumusan tersebut diatas merupakan "ekses" dari kasus Marbury vs Madison pada tahun 1803, yang kemudian memberikan wewenang judicial review kepada Mahkamah Agung Amerika Serikat (US Supreme Court) untuk menguji undang-undang yang dibuat oleh Kongres terhadap Konstitusi Amerika Serikat ${ }^{9}$, dan kemudian menjadi semacam "preseden" terhadap pembentukan Mahkamah Konstitusi pertama di dunia, yaitu di Austria pada tahun 1920, dan selanjutnya "menular" ke negara-negara lainnya.

Di Indonesia, lembaga Judicial Review Undang-Undang terhadap Undang-Undang Dasar adalah Mahkamah Konstitusi, suatu lembaga Negara yang terbentuk sebagai salah satu hasil amandemen ketiga ${ }^{10}$ terhadap

8 Bryan A. Garnet et.al., 2009, Black's Law Dictionary, $9^{\text {th }}$ Edition, West Group, St. Paul, Minn., hlm. 924.

9 I Dewa Gede Palguna, 2005, Perspektif Teoritik Eksistensi Mahkamah Konstitusi (Pasca Perubahan UUD 1945), dalam Jurnal Konstitusi, Volume 2 Nomor 3, November 2005, Mahkamah Konstitusi Republik Indonesia, Jakarta, hal. 14. Uraian lengkap kasus Marbury vs Madison dapat dilihat dalam B. Arief Sidharta, 2007, Marbury vs Madison (1803), Kasus Yang Melahirkan Pranata Hukum Judicial Review Di Amerika Serikat, Law Review, Fakultas Hukum Universitas Pelita Harapan, Vol. VII No. 2, November 2007, hlm. 11-28.

10 UUD 1945 telah diubah/diamandemen sebanyak empat kali oleh MPR sehingga
UUD 1945 (menjadi UU Negara RI tahun 1945). Dalam pasal 24C UUD Negara RI tahun 1945 dinyatakan bahwa "Mahkamah Konstitusi berwenang mengadili pada tingkat pertama dan terakhir yang putusannya bersifat final untuk menguji UndangUndang terhadap Undang-Undang Dasar, ...".

Indonesia tercatat sebagai negara ke 78 di dunia yang membentuk/ memiliki Mahkamah Konstitusi, serta menjadi negara pertama pada abad ke 21 yang membentuk lembaga kekuasaan kehakiman tersebut ${ }^{11}$. Selain Indonesia, terdapat beberapa negara yang juga memiliki Mahkamah Konstitusi (Constitutional Court) dengan kewenangan judicial review ${ }^{12}$ undang-undang terhadap undangundang dasar/konstitusi, seperti misalnya Jerman, Polandia, Cyprus, Rusia, Belarus dan Korea Selatan. Pada beberapa negara lainnya, seperti Amerika Serikat, Jepang, Venezuela, dan Singapura, kewenangan judicial review dipegang oleh Mahkamah

menjadi UU NRI tahun 1945. Amandemen Pertama disahkan pada tanggal 19 Oktober 1999, Amandemen Kedua disahkan pada tanggal 18 Agustus 2000, Amandemen Ketiga disahkan pada tanggal 9 November 2001, dan Amandemen Keempat disahkan pada tanggal 10 Agustus 2002.

11 Jimly Asshiddiqie, 2008, Mahkamah Konstitusi Dalam Sistem Ketatanegaraan Republik Indonesia (selanjutnya disingkat Jimly Asshiddiqie II), Bahan Ceramah pada Pendidikan Sespati dan Sespim Polri, Bandung, tanggal 19 April 2008.

12 Pada uraian selanjutnya, istilah "judicial review" dibatasi pada pengertian "kewenangan menguji undang-undang terhadap undangundang dasar". 
Surnal $\begin{aligned} & \text { E-ISSN 2502-3101 } \\ & \text { PIISN 2302-528X } \\ & \text { Magister Hukum Udayana }\end{aligned}$ • Juli 2016
(UDAYANA MASTER LAW JOURNAL)

Agung (Supreme Court). Sementara ada pula beberapa negara yang kewenangan judicial review nya dipegang oleh Dewan Konstitusi (Constitutional Council), seperti Perancis, Kamboja dan Kazakhstan. Di Estonia, lembaga judicial review dipegang oleh Mahkamah Nasional (NationalCourt), sementaradiRepublik Rakyat Tiongkok kewenangan tersebut dipegang oleh Komite Tetap Kongres Rakyat Nasional (Standing Committee of National People Congress). Namun demikian, ada pula beberapa negara yang tidak memiliki lembaga judicial review, seperti Belanda, Meksiko dan Peru. Tulisan ini akan mengulas tentang profil dan kewenangan lembaga judicial review yang berbentuk Mahkamah Konstitusi/ Constitutional Court di Korea Selatan, serta memperbandingkannya dengan profil dan kewenangan Mahkamah Konstitusi Republik Indonesia.

\subsection{Perumusan masalah}

Berdasarkan latar belakang sebagaimana telah diuraikan diatas, maka permasalahan yang akan dibahas dalam tulisan ini adalah : Bagaimanakah profil dan kewenangan Mahkamah Konstitusi/Constitutional Court di Korea Selatan, apabila dibandingkan dengan profil dan kewenangan Mahkamah Konstitusi Republik Indonesia?
Vol. 5, No. $2: 368$ - 379

http://ojs.unud.ac.id/index.php/jmhu

\subsection{Tujuan Penelitian \\ 1.3.1. Tujuan Umum}

Untuk memperbandingkan profil serta terutama kewenangan antara Mahkamah Konstitusi/Constitutional Court di Korea Selatan yang telah lebih dahulu ada, dengan Mahkamah Konstitusi Republik Indonesia yang lahir belakangan, sehingga dapat dilihat kekurangan dan kelebihan masing-masing.

\subsubsection{Tujuan Khusus}

Untuk dapat menganalisis serta - jika mungkin - memberi masukanmasukan demi penyempurnaan Mahkamah Konstitusi Republik Indonesia, baik dari sisi profil maupun kewenangannya, sehingga diharapkan agar Mahkamah Konstitusi Republik Indonesia dapatmemberikankontribusi yang lebih baik sebagai the guardian of the constitution.

\section{METODE PENELITIAN}

Metode yang digunakan adalah metode penelitian hukum normatif, yaitu riset kepustakaan, dengan pendekatan perundangundangan/statutory approach serta pendekatan perbandingan/comparative approach $^{13}$. Bahan hukum yang digunakan terdiri dari bahan hukum primer berupa konstitusi dan peraturan perundang-undangan yang terkait dengan topik bahasan, sedangkan 13 Periksa Soerjono Soekanto, 2005, Pengantar Penelitian Hukum, UI Press, Jakarta, hal. 51, dan Peter Mahmud Marzuki, 2010, Penelitian Hukum, Prenada Media Group, Jakarta, hlm. 93. 
bahan hukum sekunder berupa textbooks, jurnal-jurnal hukum, karya tulis hukum, pandangan ahli hukum, kamus dan ensiklopedi hukum serta situs-situs internet yang relevan dan kredibel $^{14}$

III. HASIL DAN PEMBAHASAN

3.1. Mahkamah Konstitusi (The Constitutional Court) Korea Selatan.

Dalam Konstitusi Korea Selatan,

The Constitutional Court (Mahkamah Konstitusi) diatur dalam Bab VI Pasal 111 sampai dengan Pasal $113^{15}$, sebagai berikut:

Article 111 (Pasal 111).

(1) The Constitutional Court shall have jurisdiction over the following matters (Mahkamah Konstitusi berwenang atas hal-hal sebagai berikut):

1) The constitutionality of a law upon the request of the courts (Konstitusionalitas suatu undang-undang atas permintaan pengadilan);

2) Impeachment (Pemakzulan);

3) Dissolution of a political party (Pembubaran partai politik);

4) Competence disputes between State agencies, between State agencies and local governments,

14 Program Studi Magister (S2) Ilmu Hukum, Program Pasca Sarjana Universitas Udayana, 2013, Pedoman Penulisan Usulan Penelitian Tesis dan Penulisan Tesis Program Studi Magister (S2) Ilmu Hukum, Universitas Udayana, Denpasar, hlm. 29-31.

15 South Korea Constitution, dikutip dari http://.wipo.int/wipolex/en/text.jsp?file id=214459, diakses tanggal 15 Juli 2015.
Vol. 5, No. $2: 368$ - 379

http://ojs.unud.ac.id/index.php/jmhu

\section{5)}

5) Constitutional complaint as prescribed by Act (Pengaduan konstitusional sebagaimana ditentukan oleh undangundang).

(2) The Constitutional Court shall be composed of nine Justices qualified to be court judges, and they shall be appointed by the President (Mahkamah Konstitusi terdiri dari sembilan hakim yang memenuhi syarat untuk menjadi hakim pengadilan, dan mereka diangkat oleh Presiden).

(3) Among the Justices referred to in Paragraph (2), threeshall beappointed from persons selected by the National Assembly, and three appointed from persons nominated by the Chief Justice of the Supreme Court (diantara hakim-hakim sebagaimana tersebut pada ayat (2), tiga orang diangkat dari orang-orang yang dipilih oleh Majelis Nasional, dan tiga orang diangkat dari orang-orang yang dicalonkan oleh Ketua Mahkamah Agung).

(4) The head of the Constitutional Court shall be appointed by the President from among the Justices with the consent of the National Assembly (Ketua Mahkamah Konstitusi diangkat oleh Presiden dari antara Hakimhakim Mahkamah Konstitusi dengan persetujuan Majelis Nasional). 
Article 112 (Pasal 112).

(1) The term of office of the Justices of the Constitutional Court shall be six years, and they may be reappointed under the conditions as prescribed by Act (Masa jabatan para hakim Mahkamah Konstitusi adalah enam tahun, dan dapat diangkat kembali sesuai dengan ketentuan undangundang).

(2) The Justices of the Constitutional Court shall not join any political party nor shall they participate in political activities (Hakim-hakim Mahkamah Konstitusi tidak boleh menjadi anggota partai politik atau berpartisipasi dalam aktivitas politik).

(3) No Justice of the Constitutional Court shall be expelled from the office except by impeachment or a sentence of imprisonment without prison labor or heavier punishment (Tidak seorang pun dari hakim Mahkamah Konstitusi dapat diberhentikan dari jabatannya kecuali oleh pemakzulan atau dihukum penjara atau hukuman yang lebih berat).

Article 113 (Pasal 113).

(1) WhentheConstitutionalCourtmakes a decision of the unconstitutionality of a law, a decision of impeachment, a decision of dissolution of a political party, or an affirmative decision regarding the constitutional complaint, the concurrence of six Justices or more shall be required (Dalam hal Mahkamah Konstitusi membuat keputusan tentang inkonstitusionalitas
Vol. 5, No. 2 : 368 - 379

http://ojs.unud.ac.id/index.php/jmhu suatu aturan hukum, pemakzulan, pembubaran partai politik, atau suatu persetujuan terhadap suatu pengaduan konstitusional, diperlukan persetujuan enam hakim konstitusi atau lebih).

(2) The Constitutional Court may establish regulations relating to its proceedings and internal discipline and regulations on administrative matters within the limits of Act (Mahkamah Konstitusi dapat membuat peraturan yang berkaitan dengan proses dan peraturan internal, serta peraturanperaturan yang bersifat administratif dibatasi dengan undang-undang).

(3) The organization, function, and other necessary matters of the Constitutional Court are determined by Act (Organisasi, fungsi, serta hal-hal lain yang diperlukan oleh Mahkamah Konstitusi diatur dengan undangundang).

Sebagai tindak lanjut dari "perintah" Konstitusi pasal 113 ayat (3) tersebut diatas, maka diterbitkan Undang-undang Mahkamah Konstitusi Korea Selatan (Constitutional Courts $A c t$ ), mulai berlaku mulai tanggal 5 Agustus 1988, dan sampai saat ini sudah sebelas kali di amandemen, yang pertama pada tanggal 30 November 1991, dan terakhir pada tanggal 14 Maret 2008. Beberapa pasal yang menyangkut profil ${ }^{16}$ dan kewenangan lembaga ini dapat dikemukakan sebagai berikut :

16 Yang dimaksud dengan Profil dalam bahasan ini hanya menyangkut Komposisi Hakim, Kualifikasi Hakim, Pengangkatan Hakim, dan Masa Jabatan Hakim. 
Article 2 - Jurisdiction (Pasal 2 Kewenangan)

The Constitutional Court shall have the authority to decide on the following (Mahkamah Konstitusi mempunyai wewenang untuk memutuskan hal-hal berikut) :

1. Constitutionality of statutes at the request of ordinary courts (Konstitusionalitas undangundang atas permintaan pengadilan),

2. Impeachments (Pemakzulan),

3. Dissolution of political parties (Pembubaran partai politik),

4. Competence disputes between state agencies, between state agencies and a local government, or between local governments ((Sengketa kewenangan antar lembaga Negara, antara lembaga Negara dengan pemerintahan daerah, serta antar pemerintahan daerah),

5. Constitutional complaints (Pengaduan Konstitusional).

Article 3 - Composition (Pasal 3 Komposisi)

The Constitutional Court shall consist of nine (9) Justices (Mahkamah Konstitusi terdiri dari sembilan (9) hakim).

Article 5 - Qualifications of Justices (Kualifikasi Hakim)

(1) The Justices must have reached the age of forty and be appointed from among those who have held one of the following positions for fifteen or more years. Provided, that in case a person has held two or more of the following positions, the period of service shall be aggregated (Hakim harus telah mencapai usia empat puluh dan diangkat dari antara mereka yang telah memegang salah satu posisi berikut untuk lima belas tahun atau lebih. Asalkan, bahwa dalam hal seseorang telah memegang dua atau lebih jabatan sebagai berikut, masa jabatan harus digabungkan):

1. A Judge, a Public Prosecutor or an Attorney (Hakim, Jaksa atau Pengacara),

2. A person licensed to practice law who has been engaged in legal work at a state agency, a state owned or public enterprise, a government-invested institution or other corporation (Seseorang yang memiliki lisensi untuk praktik hukum, yang telah terlibat dalam pekerjaan dibidang hukum pada lembaga negara, badan usaha milik negara atau perusahaan publik, lembaga investasi pemerintah atau korporasi lainnya),

3. A person licensed to practice law who has held the position of assistant professor of law or higher at an accredited college or university (Seseorang yang memiliki lisensi untuk praktik hukum, yang memegang posisi asisten profesor dibidang hukum atau lebih pada perguruan tinggi atau universitas ter akreditasi). 
Article 6-Appointment of Justice (Pasal 6 - Pengangkatan Hakim)

(1) The Justices shall be appointed by the Presidentof the Republic. Among the Justices, three shall be appointed from those elected by National Assembly, and three from those designated by the Chief Justice of the Supreme Court (Para Hakim Konstitusi diangkat oleh Presiden Republik. Diantara para Hakim, tiga diangkat dari mereka yang dipilih oleh Majelis Nasional, dan tiga orang ditunjuk oleh Ketua Mahkamah Agung).

Article 7 - Terms of Justice (Pasal 7 - Masa Jabatan Hakim)

(1) The term of Justices shall be six years and mau be renewed (Masa jabatan Hakim adalah enam tahun dan dapat diperpanjang)

(2) The retirement age of Justices shall be sixty five. Provided, that the retirement age of the President of the Constitutional Court shall be seventy (Usia pensiun Hakim adalah enam puluh lima tahun. Usia pensiun Presiden Mahkamah Konstitusi adalah tujuh puluh tahun).

Article 9 - Prohibition of Justices' Participation in Politics (Larangan partisipasi Hakim di Politik)

No Justice shall be permitted to join a political party or participate in politics (Hakim dilarang bergabung dalam partai politik atau berpartisipasi dalam politik).
Vol. 5, No. 2 : 368 - 379

http://ojs.unud.ac.id/index.php/jmhu

\subsection{Profil dan Kewenangan Mahkamah Konstitusi Republik Indonesia}

Eksistensi Mahkamah Konstitusi Republik Indonesia (selanjutnya disingkat MKRI) dimulai saat terjadi amandemen ketiga terhadap UUD 1945 menjadi UUD Negara RI tahun 1945, disahkan pada rapat paripurna MPR pada tanggal 9 November 2001. Dalam UUD Negara RI tahun 1945, MKRI diatur dalam pasal 24C sebagai berikut :

Pasal 24C

(1) Mahkamah Konstitusi berwenang mengadili pada tingkat pertama dan terakhir yang putusannya bersifat final untuk menguji undangundang terhadap UndangUndang Dasar, memutus sengketa kewenangan lembaga negara yang kewenangannya diberikan olehUndang-Undang Dasar, memutus pembubaran partai politik, dan memutus perselisihan tentang hasil pemilihan umum.

(2) Mahkamah Konstitusi wajib memberikan putusan atas pendapatDewanPerwakilan Rakyat mengenai dugaan pelanggaran oleh Presiden dan/atau Wakil Presiden menurut Undang-Undang Dasar.

(3) Mahkamah Konstitusi mempunyai sembilan 
orang hakim konstitusi yang ditetapkan oleh Presiden, yang diajukan masing-masing tiga orang oleh Mahkamah Agung, tiga orang oleh Dewan Perwakilan Rakyat, dan tiga orang oleh Presiden.

(4) Ketua dan Wakil Ketua Mahkamah Konstitusi dipilih dari dan oleh hakim konstitusi.

(5) Hakim konstitusi harus memiliki integritas dan kepribadian tidak tercela, adil, negarawan yang menguasai konstitusi dan ketatanegaraan, serta tidak merangkap sebagai pejabat negara.

(6) Pengangkatan dan pemberhentian hakim konstitusi, hukum acara serta ketentuan lainnya tentang Mahkamah Konstitusi diatur dengan undang-undang.

Menindaklanjuti "perintah" pasal 24C ayat (6) tersebut diatas, undang-undang yang mengatur tentang MKRI adalah UU No. 24 tahun 2003 tentang Mahkamah Konstitusi yo UU No. 8 tahun 2011 tentang Perubahan atas UU No. 24 tahun 2003 tentang Mahkamah Konstitusi yo UU No. 4 tahun 2014 tentang Penetapan Peraturan Pemerintah Pengganti Undang-Undang No.1 tahun 2013 tentang Perubahan Kedua atas UU
No. 24 tahun 2003 tentang Mahkamah Konstitusi Menjadi Undang-Undang. Beberapa pasal dalam Undang-undang tersebut yang menyangkut profil dan kewenangan MKRI antara lain adalah:

Kewenangan - Pasal 10 ayat (1) UU No. 24 tahun 2003 : Mahkamah Konstitusi berwenang mengadili pada tingkat pertama dan terakhir yang putusannya bersifat final untuk :

a. Menguji undang-undang terhadap Undang-Undang Dasar Negara Republik Indonesia tahun 1945,

b. Memutus sengketa kewenangan lembaga Negara yang kewenangannya diberikan oleh Undang-Undang Dasar Negara Republik Indonesia tahun 1945,

c. Memutus pembubaran partai politik, dan

d. Memutus perselisihan tenang hasil pemilihan umum.

Pasal 10 ayat (2) UU No. 24 tahun 2003 : Mahkamah Konstitusi wajib memberikan putusan atas pendapat DPR bahwa Presiden dan/ atau Wakil Presiden diduga telah melakukan pelanggaran hukum berupa pengkhianatan terhadap negara, korupsi, penyuapan, tindak pidana berat lainnya, atau perbuatan tercela, dan/atau tidak lagi memenuhi syarat sebagai Presiden dan/atau Wakil Presiden sebagaimana dimaksud dalam Undang-Undang Dasar Negara Republik Indonesia tahun 1945. 
Komposisi - Mahkamah Konstitusi mempunyai 9 (sembilan) orang anggota Hakim Konstitusi yang ditetapkan dengan Keputusan Presiden (Pasal 4 ayat (1) UU No. 8 tahun 2011).

Kualifikasi Hakim - Hakim

Konstitusi harus memenuhi syarat : a). memiliki integritas dan kepribadian yang tidak tercela, b). adil, dan c). negarawan yang menguasai konstitusi dan ketatanegaraan (Pasal 15 ayat (1) UU No. 4 tahun 2014). Untuk dapat diangkat menjadi hakim konstitusi, selain harus memenuhi syarat sebagaimana dimaksud pada ayat (1), seorang calon hakim konstitusi harus memenuhi syarat : a) WNI, b). berijazah Doktor dengan dasar sarjana yang berlatar belakang pendidikan tinggi hukum, c). bertaqwa kepada Tuhan YME dan berakhlak mulia, d). berusia paling rendah 47 (empat puluh tujuh) tahun dan paling tinggi 65 (enam puluh lima) tahun pada saat pengangkatan, e). mampu secara jasmani dan rohani dalam menjalankan tugas dan kewajiban, f). tidak pernah dijatuhi pidana penjara berdasarkan putusan pengadilan yang telah memperoleh kekuatan hukum tetap, g). tidak sedang dinyatakan pailit berdasarkan putusan pengadilan, h). mempunyai pengalaman kerja di bidang hukum paling sedikit 15 (lima belas) tahun, dan i). tidak menjadi anggota partai politik dalam jangka waktu paling singkat 7 (tujuh) tahun sebelum diajukan sebagai calon hakim konstitusi (Pasal 15 ayat (2) UU No. 4 tahun 2014).

Pengangkatan Hakim - Hakim konstitusi diajukan masing-masing 3 (tiga) orang oleh Mahkamah Agung, 3 (tiga) orang oleh DPR, dan 3 (tiga) orang oleh Presiden, untuk ditetapkan dengan Keputusan Presiden (Pasal 18 ayat (1) UU No. 24 tahun 2003).

Masa Jabatan Hakim - Masa jabatan hakim konstitusi selama 5 (lima) tahun dan dapat dipilih kembali hanya untuk 1 (satu) kali masa jabatan berikutnya (Pasal 22 UU No. 24 tahun 2003).

\subsection{Perbandingan Antara}

Constitutional Court Korea Selatan Dengan Mahkamah Konstitusi Republik Indonesia

Atas uraian tentang profil dan kewenangan dari Constitutional Court Korea Selatan dan Mahkamah Konstitusi Republik Indonesia tersebut diatas, terlihat adanya persamaan maupun perbedaan diantara keduanya. Dari sisi profil, secara umum lebih banyak terlihat adanya persamaan diantara keduanya, seperti komposisi dan jumlah Hakim (sembilan orang, masing-masing tiga orang dari unsur Yudikatif/Mahkamah Agung, tiga orang dari Legislatif/DPR/Majelis Nasional, dan tiga orang dari Eksekutif/Presiden). Demikian pula syarat non-partisan bagi hakim, serta pengalaman kerja dibidang hukum. Perbedaan hanya terjadi pada masa jabatan serta usia hakim yang tidak terlalu menyolok. 
Perbedaan yang Nampak jelas justru ada pada kewenangan diantara keduanya, yang diatur dalam konstitusi masing-masing. Constitutional Court Korea Selatan mempunyaikewenangan Constitutional complaints (pengaduan konstitutional) yang tidak dimiliki oleh Mahkamah Konstitusi Republik Indonesia ${ }^{17}$.

\section{PENUTUP}

\subsection{Simpulan}

Atas keseluruhan pembahasan tersebut diatas, dapat dirumuskan kesimpulan sebagai berikut: Pertama dari sisi profil, terdapat lebih kesamaan atau kemiripan antara Constitutional CourtKoreaSelatan dengan Mahkamah Konstitusi Republik Indonesia. Perbedaan hanya terdapat pada masa jabatan, serta pada usia hakim. Kedua dari sisi kewenangan yang diberikan, baik oleh Konstitusi/UUD maupun oleh Undang-undang terkait, terlihat bahwa perbedaan utamanya pada dimilikinya wewenang Pengaduan Konstitusional (Constitutional Complaint) pada Mahkamah Konstitusi Korea Selatan, yang tidak dimiliki oleh Mahkamah Konstitusi Republik Indonesia.

\subsection{Saran}

Mengingat dinamika perkembangan yang terjadi, Mahkamah Konstitusi Republik Indonesia perlu

\footnotetext{
Lebih jauh mengenai hal ini, periksa I Dewa Gede Palguna, 2013, Pengaduan Konstitusional (Constitutional Complaint). Upaya Hukum Terhadap Pelanggaran HakHak Konstitusional Warga Negara, Sinar Grafika, Jakarta, hlm. 593-601.
}

memiliki wewenang Pengaduan Konstitusional (Constitutional Complaint) melalui amandemen terhadap UUD Negara RI tahun 1945.

\section{DAFTAR PUSTAKA}

B. Arief Sidharta, 2007, Marbury vs Madison (1803), Kasus Yang Melahirkan Pranata Hukum Judicial Review Di Amerika Serikat, Law Review, Fakultas Hukum Universitas Pelita Harapan, Vol. VII No. 2, November 2007.Bryan A. Garnet et.al., 2009, Black's Law Dictionary, $9^{\text {th }}$ Edition, West Group, St. Paul, Minn.I Dewa Gede Palguna, 2005, Perspektif Teoritik Eksistensi Mahkamah Konstitusi (Pasca Perubahan UUD 1945), dalam Jurnal Konstitusi, Volume 2 Nomor 3, November 2005, Mahkamah Konstitusi Republik Indonesia, Jakarta.

2013, Pengaduan

Konstitusional (Constitutional

Complaint): Upaya Hukum Terhadap Pelanggaran Hak-Hak Konstitusional Warga Negara, Sinar Grafika, Jakarta.

Jimly Asshiddiqie, 2006, Hukum Acara Pengujian Undang-Undang, Konstitusi Press, Jakarta. , 2008, Mahkamah Konstitusi

Dalam Sistem Ketatanegaraan Republik Indonesia , Bahan Ceramah pada Pendidikan Sespati dan Sespim Polri, 
Bandung, tanggal 19 April Undang-Undang No. 4 tahun 2014 2008.

John. M. Echols dan Hassan Shadili, tentang Penetapan Peraturan 1993, Kamus Inggris-Indonesia, Pemerintah Pengganti Undang(An English-Indonesian Undang No.1 tahun 2013 Dictionary), PT Gramedia tentang Perubahan Kedua atas Pustaka Utama, Jakarta.

Hans Kelsen, 2006, General Theory of Law and State, with new introduction by A. Javier Trevino, Transaction Publisher, New Brunswick (USA) and UU No. 24 tahun 2003 tentang Mahkamah Konstitusi Menjadi Undang-Undang.

South Korea Constitution, http:// www.wipo.int/wipolex/en/text. jsp?file_id=214459

London (UK).

Peter Mahmud Marzuki, 2010, Penelitian Hukum, Prenada Media Group, Jakarta.

Program Studi Magister (S2) Ilmu Hukum, Program Pasca Sarjana Universitas Udayana, 2013, Pedoman Penulisan Usulan Penelitian Tesis dan Penulisan Tesis Program Studi Magister (S2) Ilmu Hukum, Universitas Udayana, Denpasar.

Soerjono Soekanto, 2005, Pengantar Penelitian Hukum, UI Press, Jakarta.

\section{PERATURAN PERUNDANG} UNDANGAN

Undang-Undang Dasar Negara Republik Indonesia tahun 1945

Undang-Undang No. 24 tahun 2003 tentang Mahkamah Konstitusi

Undang-Undang No.8 tahun 2011 tentang Perubahan atas UU No. 24 tahun 2003 tentang Mahkamah Konstitusi. 